\title{
触 New Disease Reports \\ First report of Epicoccum nigrum causing disease in Lotus corniculatus in Argentina
}

\author{
B. Colavolpe, J. Ezquiaga, S. Maiale* and O. Ruiz
}

IIB-INTECH (UNSAM-CONICET), Avenue Intendente Marino km 8.2, 7130 Chascomús, Argentina

*E-mail: smaiale@intech.gov.ar

Received: 28 Jun 2018. Published: 04 Aug 2018. Keywords: fungal plant disease, Lotus tenuis

Lotus corniculatus is a species adapted to field conditions in the most important cattle production region in Argentina and constitutes a very valuable forage species. In January 2018, black leaf spots were observed on L. corniculatus (Fig. 1) in field plots in Chascomús, Buenos Aires. These spots were amphigenous, circular to irregular, 2-8 $\mathrm{mm}$ diameter, close to the leaf margin and reddish brown. Single lesions often coalesced to form arger lesions and became dark brown (Fig. 1)

Fungal isolates were obtained from the shoot lesions and were incubated on oatmeal agar, malt extract and potato dextrose agar (Crous et al., 2009) at $25^{\circ} \mathrm{C}$ in darkness. Macroscopic features of colonies on these media and mycelia characteristic were characterised under a microscope (Fig. 2) and conformed morphologically most closely to the genus Epicoccum (Chen et al., 2017). Total genomic DNA was extracted from fresh mycelia and PCR amplification was done using the ITS4 and ITS5 primers (White et al., 1990) designed to amplify the internal transcribed spacer (ITS) region. The amplified PCR products were purified and sequenced (GenBank Accession No. MH042300). A BLAST search revealed $99 \%$ identity to E. nigrum (KX815296 and MF510615).

An inoculation trial was done as follows. Lotus corniculatus plants were grown in a growth chamber at $25^{\circ} \mathrm{C}$ at $30-40 \%$ relative humidity with a 12 $\mathrm{hr}$ photoperiod. Thirty-day-old leaves were placed on Petri plates containing water agar medium. Leaves were sprayed with a conidia solution prepared by agitating the fungal lawn with distilled water in a petri dish culture, then suspending in $0.05 \%$ Tween 20 to a final concentration of $10^{5}$ conidia/ml. Control leaves were sprayed with water containing $0.05 \%$ Tween 20 . Petri plates were maintained at $25^{\circ} \mathrm{C}, 100 \%$ relative humidity for 16 days. The inoculated $L$. corniculatus plants were observed to be wilted with a yellow appearance and black spots (Fig. 3). The causal fungus was isolated and the macro- and microscopic characteristics were consistent with the inoculated fungus.
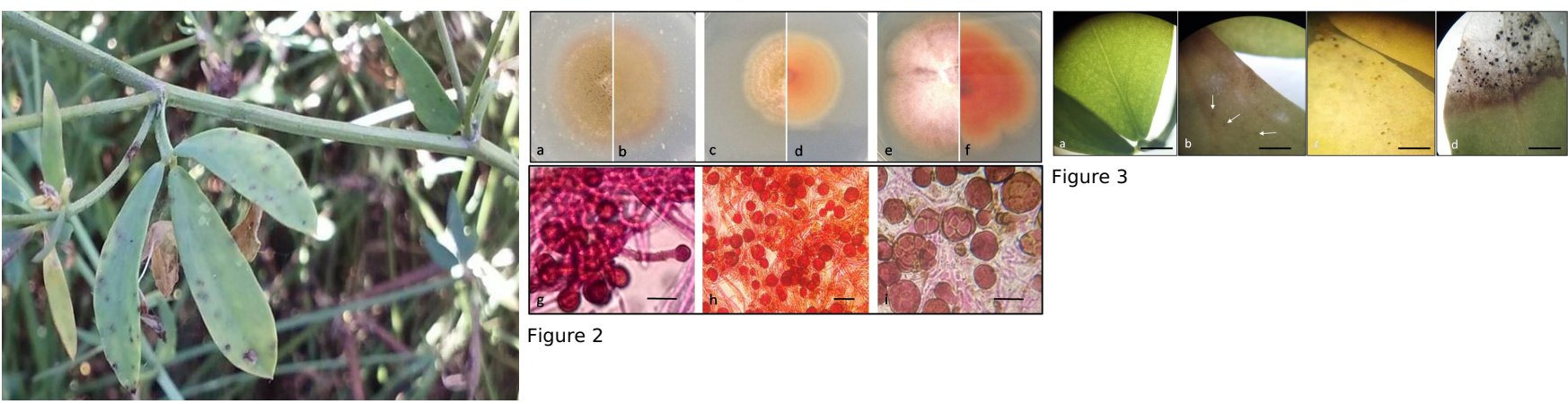

Figure 3
The genus Epicoccum was reported in Argentina as a seed pathogen in Lotus spp. (Sisterna \& Lori, 2005). The isolate in the current study had 98\% identity with E. nigrum (KC568289 and KY303832) that caused leaf spot in Lablab purpureus and brown leaf spot in loquat, respectively (Mahadevakumar et al., 2014; Wu et al., 2017). To our knowledge, this is the first report of E. nigrum causing leaf spot in L. corniculatus in Argentina.

\section{References}

Chen Q, Hou LW, Duan WJ, Crous PW, Cai L, 2017. Didymellaceae revisited. Studies in Mycology 87, 105-159. http://dx.doi.org/10.1016/j.simyco.2017.06.002

Crous PW, Verkley GJM, Groenewald JZ, Samson RA, eds. 2009. Fungal Biodiversity. CBS Laboratory Manual Series, Volume 1. Utrech, The Netherlands: Westerdijk Fungal Biodiversity Institute.

Mahadevakumar S, Jayaramaiah KM, Janardhana GR, 2014. First report of leaf spot disease caused by Epicoccum nigrum on Lablab purpureus in India. Plant Disease 98, 284. http://dx.doi.org/10.1094/PDIS-07-13-0798

Sisterna M, Lori G, 2005. Fungal diseases on Lotus spp. in Argentina. Lotus Newsletter 35, 15-16.

White TJ, Bruns T, Lee S, Taylor JW, 1990. Amplification and direct sequencing of fungal ribosomal RNA genes for phylogenetics. In: Innis MA, Gelfand DH, Sninsky JJ, White TJ, eds. PCR Protocols: A Guide to Methods and Applications. New York, USA: Academic Press Inc., 315-322. http://dx.doi.org/10.1016/B978-0-12-372180-8.50042-1

Wu D, Zhang DH, Timko MP, Li MY, Liang JL. 2017. First report of Epicoccum nigrum causing brown leaf spot of loquat in southwestern China. Plant Disease, 1553. http://dx.doi.org/10.1094/PDIS-12-16-1840

Figure 1

To cite this report: Colavolpe B, Ezquiaga J, Maiale S, Ruiz O, 2018. First report of Epicoccum nigrum causing disease in Lotus corniculatus in Argentina. New Disease Reports 38, 6. http://dx.doi.org/10.5197/j.2044-0588.2018.038.006 